\title{
The Effect of Internal Communication on Employee Performance in Informal Education Institutions: The Role of Organizational Commitment as a Mediation Variable
}

\author{
Wiwin Endang Saefuddin Mubarok Subari Aryanda \\ Faculty of Economics, Jakarta Islamic University, Jakarta, Indonesia
}

\begin{abstract}
Human resources have a strategic role, especially for informal educational institutions in Indonesia. However, research on how to improve employee performance in informal educational institutions is still limited. This study aims to examine the effect of internal communication on employee performance in informal educational institutions by considering organizational commitment as a mediating variable. This study uses a survey method to collect data relevant to the research objectives. The sample involved was 116 employees from 14 informal educational institutions located in Kampung Inggris, Pare, Indonesia. The results showed that internal communication had a positive impact on employee performance and organizational commitment. It is also found that organizational commitment has a positive impact on employee performance. In addition, organizational commitment significantly mediates the relationship between internal communication and employee performance. This finding implies that informal educational institutions need to build an effective internal communication system as a medium to foster organizational commitment and employee performance.
\end{abstract}

Keywords: internal communication, organizational commitment, employee performance, Indonesian informal educational institutions

DOI: $10.7176 / \mathrm{EJBM} / 12-32-05$

Publication date: November $30^{\text {th }} 2020$

\section{Introduction}

The existence of human resources is the most important factor for the realization of a predetermined organizational plan. The role of human resources will be increasingly important, especially in the era of globalization which is full of challenges. Thus, it is important for an organization to manage their human resources. If an organization is capable of managing their human resources, the organization will benefit greatly, namely the achievement of the stated organizational goals, and vice versa (Vercic et al., 2012). Human resources are an important asset for an organization because human resources have roles and functions that cannot be replaced by other resources. Even though the organization provides other resources such as technology and finance adequately, without professional human resources, these other resources are meaningless (Rukmana et al., 2018).

In the present, one of the challenges that must be faced by an organization is determining ways to improve the performance of their employees because employee performance will affect the overall performance of the organization. According to Riketta (2002), performance is the result of an employee's work in quality and quantity in carrying out his duties in accordance with the responsibilities that have been given to the employee. Storey (2004) suggests that employee performance is high if a work target can be completed at the right time or does not exceed the time limit provided. Performance becomes low if it is completed beyond the allotted time limit or is not completed at all. According to Bhatia and Balani (2015), there are six primary criteria for measuring performance in terms of quality, quantity, timeliness, cost, supervision, and personal impact.

To ensure the continuity of an organization in the midst of competition, and in order to achieve the stated goals and vision and mission, an organization is required to be able to improve the performance of its employees. The literature shows that employee performance can be influenced by external factors as well as internal factors (Giri and Kumar, 2010). This study focuses on internal factors by examining the impact of internal communication and organizational commitment on employee performance at English language course institutions, which are located in Kampung Inggris, Pare Regency, Indonesia. This study assumes that employee performance is one of the most important determinants for organizations in achieving long-term competitive advantage and that employee performance is one of the determining factors for organizational success.

The first factor that is thought to have influenced employee performance is the internal communication that takes place within the organization. According to Kalla (2005), communication is the process of delivering information from one individual to another to achieve a goal. Communication can also be referred to as a process of transferring information, ideas and understanding from one person to another in the hope that the recipient of the information can capture the intended purpose. Internal communication is the process of delivering messages that take place between organizational members. This communication can take place between leaders and employees, leaders and leaders, and employees and employees. Internal communication can also be interpreted 
as sending messages to all members of the organization. Thus, the recipients of messages in internal communication are individuals who are in the organization.

The second factor that is thought to have influenced employee performance is organizational commitment owned by organizational employees. According to Yeh (2012), organizational commitment is a form of a person's work attitude that reflects the feelings of employees towards the organization. Organizational commitment is an employee orientation that includes loyalty, identification and involvement. Organizational commitment also refers to the tendency of employees to engage in organizational activities consistently because they think there are costs in carrying out other activities. In addition, organizational commitment indicates a strong desire of employees to become members of a group, a high willingness of effort for the organization, a high willingness of effort for the organization.

\section{Literature review and hypothesis development}

\subsection{Internal Communication}

According to Femi (2014), communication is the process of delivering information from one individual to another to achieve a goal. Communication can also be referred to as a process of transferring information, ideas and understanding from one person to another in the hope that the recipient of the information can capture the intended purpose (Fletcher, 1999). Internal communication is the process of delivering messages that take place between organizational members. This communication can take place between leaders and employees, leaders and leaders, and employees and employees (Hume and Leonard, 2014). Internal communication can also be interpreted as sending messages to all members of the organization. Thus, the recipients of messages in internal communication are individuals who are in the organization (Kulachai et al., 2018). Referring to Meng and Pan (2012), internal communication can be interpreted as an exchange of ideas between administrators and employees in a company or organization that causes the creation of the company or organization complete with its distinctive structure. This exchange of ideas can take place horizontally and vertically in a company or organization that causes operations and management within the company or organization to take place.

The line of communication from superiors to subordinates is the delivery of information or messages in the form of orders, instructions, or procedures to be carried out by subordinates as well as possible. To achieve the desired goal, it is necessary to pay attention to the use of language that is appropriate, simple, straightforward, and easy to understand in delivering messages (Welch, 2013). In a work climate, instruction is something that is often done in the context of communication from superiors to subordinates. These instructions can be carried out orally or in writing. Work orders or instructions can be in the form of teaching something new or disseminating to employees how to do specific tasks. According to Welch (2013), communication from top to bottom has five main objectives, namely providing specific work directions or instructions, providing information on why a job must be carried out, providing information about organizational procedures and practices, providing feedback on work implementation to employees, and providing information about ideological aspects in helping organizations instill an understanding of the goals to be achieved.

In an organization, bottom-up communication means the flow of messages sent from employees to leaders. The message to be conveyed first comes from the employees, which is then conveyed to a higher level (Men and Stacks, 2014). According to Men and Stacks (2014), upward communication is important for several reasons as follows. Bottom-up information flow provides valuable information for decision-making by those who direct the organization and supervise people's activities, upward communication tells when their subordinates are ready to receive information from them and how well subordinates accept what they say, upward communication is possible or even encouraging problems to surface so that superiors know what is bothering those closest to actual operations, upward communication fosters appreciation and loyalty to the organization by giving employees the opportunity to ask questions and contribute ideas and suggestions regarding organizational operations, upward communication determine whether subordinates understand what is expected from the downward flow of information, and upward communication helps employees solve their job problems and strengthen their engagement with their work and with the organization. Referring to Neill and Jiang (2017), horizontal communication is communication that occurs between individuals or parts who have an equal or equal position in an organization. The objectives of horizontal communication include coordinating work assignments, sharing information about plans and activities, to solve problems, to gain mutual understanding, to reconcile, negotiate and mediate differences, to foster support among others.

\subsection{Organizational commitment}

According to Zangaro (2001), organizational commitment is one form of a person's work attitude that reflects individual feelings towards the organization. Robbins defines organizational commitment as an individual orientation towards the organization that includes loyalty, identification and involvement. Meanwhile, Gunlu et al. (2010) defines organizational commitment as the tendency of individuals to engage in organizational activities consistently because they think there are costs in carrying out other activities. According to Hanaysha 
(2016), organizational commitment indicates a strong desire of individuals to become members of a group, a high willingness of effort for the organization, a high willingness of effort for the organization.

According to Allen and Meyer (1990), organizational commitment can be divided into three, namely affective commitment, continuous commitment, and normative commitment. Affective commitment refers to emotional attachment, identification and involvement in an organization. In this case the individual stays in an organization because of his own will. Continuous commitment is related to individual commitment which is based on consideration of what to sacrifice when leaving the organization. In this case the individual decides to stay in an organization because he considers it a fulfillment of needs. Meanwhile, normative commitment is an individual's belief about responsibility towards the organization. Individuals remain in an organization because they feel obliged to be loyal to the organization.

According to Yeh (2012), organizational commitment is a belief that connects feelings of organizational values and goals with individual values and goals. Organizational commitment represents the level of affection, loyalty, and employee concentration on job roles in an organization. Organizational commitment shows that individual goals are the same or identical to organizational goals and can stimulate employee productivity and loyalty. If members in an organization believe in and accept the organization's values, they are more willing to work hard to achieve organizational goals and have more organizational commitment. High organizational commitment will be beneficial for an organization because it indicates that employees have high organizational identification.

Organizational commitment is a strong desire to remain as a member of a particular organization, a desire to strive in accordance with the wishes of the organization, as well as certain beliefs and acceptance of organizational values and goals. In other words, organizational commitment is an attitude that reflects employee loyalty to the organization. Organizational commitment can also be viewed as a continuous process in which organizational members express their concern for the organization and the success and progress of the organization in a sustainable manner (Mathieu and Zajac, 1990).

Furthermore, Spanuth and Wald (2017) explain that employees who are highly committed will work better than employees who are less committed. According to Yeh (2012), there are at least five factors that can be used to measure employee organizational commitment, namely a strong intention to maintain membership in the organization, acceptance of the organization's main goals and values, positive evaluation in the organization, intention to work towards organizational goals, and willingness to exert considerable effort on behalf of the organization.

Referring to Allen and Meyer (1990), organizational commitment can be classified into three dimensions, namely desire (affective commitment), need (continuous commitment), and obligation (normative commitment) to maintain in the organization. Organizational commitment can be a beneficial factor for employee behavior and work results and a reduction in turnover rates for individuals in an organization.

There are several researchers who have examined the relationship between organizational commitment and employee performance. For example, Yeh (2012) examined the effect of organizational commitment on leadership style and employee performance in Taiwanese companies operating in China. His research found that organizational commitment has a positive effect on employee performance. Based on the above discussion, this study formulates a hypothesis that organizational commitment has an influence on employee performance.

\section{Research methodology}

3.1 Research design

This study aims to investigate the effect of internal communication on employee performance at English language course institutions in English-Indonesian villages: the role of organizational commitment as a mediating variable. In this study, internal communication acts as an independent variable, employee performance acts as the dependent variable, and organizational commitment acts as a mediator variable. This study uses a questionnaire as a tool to collect data relevant to the variables studied. The questionnaires were distributed directly to employees of randomly selected English course institutions in English villages. The sample involved in this study were 116 employees. This research took place from September to December 2019. The study used structural equation modeling to analyze the data collected.

\subsection{Variable measurement}

This study uses a questionnaire as a research instrument to collect data. The questionnaire consists of four parts: a section on the characteristics of the respondents, the internal communication system within the organization, organizational commitment, and the respondents' perceptions of employee performance. There are three main variables examined in this study, namely internal communication, organizational commitment, and employee performance. Referring to Fletcher (1999), this study uses eight items to measure internal communication variables. Following Allen and Meyer (1990), this study used 24 items to measure organizational commitment variables. Referring to Storey (2004), this study uses ten items to measure employee performance variables. All 
items were measured using a five-point Likert scale: ranging from 1 (strongly disagree) to 5 (strongly agree).

\subsection{Research model and hypotheses}

This study aims to investigate the effect of internal communication on employee performance at English language course institutions in English-Indonesian villages: the role of organizational commitment as a mediating variable. The conceptual framework of this research is shown in Figure 1. In this study, internal communication acts as an independent variable, employee performance acts as the dependent variable, and organizational commitment acts as a mediator variable. Based on this conceptual framework, this study proposes a working hypothesis as follows.

Hypothesis 1:

The internal communication is positively associated with the organizational commitment Hypothesis 2:

The internal communication is positively associated with the employee performance

Hypothesis 3:

The organizational commitment is positively associated with the employee performance Hypothesis 4:

The organizational commitment mediates the relationship between internal communication and the employee performance

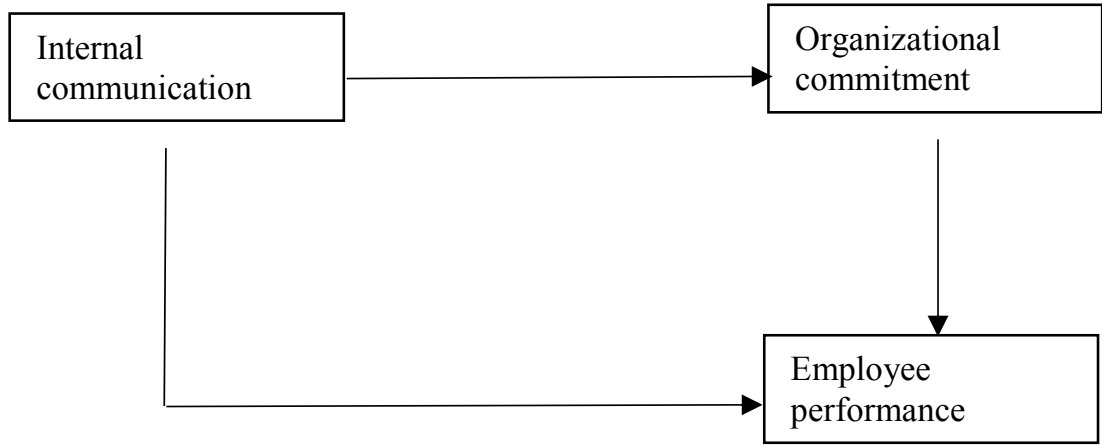

Figure 1

Conceptual framework of this study

\section{Results and Discussion}

\subsection{Overview of the respondents}

The results showed that the age of most respondents was between 30-39 years old (46 percent). This shows that most of the employees at formal educational institutions in Kampung Inggris are still young or of productive age. From the educational aspect, the largest number of respondents were from the group of respondents with a bachelor's degree (67 percent). This illustrates that most of the employees at formal educational institutions in Kampung Inggris are educated individuals. Furthermore, most of the employees have worked for employees with a service period of more than 5 - 10 years (41 percent). This shows that most of the employees at formal educational institutions in Kampung Inggris already have sufficient experience working in educational institutions.

\subsection{Validity and reliability test}

This study conducted validity and reliability tests to ensure that the instruments used in the study were valid or able to measure the measured variables appropriately. This study used Corrected item-total correlation (CITC) in testing the validity of the research instrument. In this case, an item will be declared valid if the item has a CITC greater than 0.30. Meanwhile, this study used Cronbach's alpha to test the reliability of the research instrument. The research instrument used to measure the variable will be declared reliable if the Cronbach's alpha value obtained is greater than 0.60 .

\subsection{Descriptive analysis}

This section describes a descriptive analysis of the three variables studied. For internal communication variables, this study uses eight items. These items are derived from items proposed by Fletcher (1999) to measure internal communication variables. Based on the survey results, this study found that the internal communication variable item that had the highest average value was the organizational leadership's attention item for all employees (4.6 points). Meanwhile, the item of the internal communication variable that has the lowest average value is the item of cooperation between employees and between parts of the organization (3.1 points). For the organizational commitment variable, this study uses 12 items to measure the organizational commitment variable. These 
indicators are derived from the 24 items proposed by Allen and Meyer (1990). Based on the survey results, this study found that the item of the organizational commitment variable that has the highest average value is the item of the employee's desire to continue to be part of the organization for a long time (4.4 points). Meanwhile, the item of the organizational commitment variable that has the lowest average value is the item of employee expectations to benefit from the organization if they remain as employees (3.2 points). For employee performance variables, this study uses 10 items to measure employee performance variables. These items are derived from items proposed by Storey (2004) to measure employee performance variables. Based on the survey results, this study found that the employee performance variable item that had the highest average value was the employee's item that was able to complete the assigned task in accordance with predetermined standard procedures (4.6 points). Meanwhile, the employee performance variable item that has the lowest average value is the employee's compliance item in wearing work uniforms in their daily work place (3.5 points).

\subsection{Hypothesis testing}

The first hypothesis of this study is about the relationship between internal communication and employee performance at informal educational institutions in Kampung Inggris, Pare, Indonesia. This study hypothesizes that internal communication has a positive effect on improving employee performance. In this case, Structural Equation Modeling is used to test the first hypothesis. The results of the analysis as shown in Figure 3 show that internal communication has a significant positive effect on improving employee performance $(\beta=0.182 ; p$ $<0.05)$. The results of this analysis support the first hypothesis.

The second hypothesis of this study is about the relationship between internal communication and organizational commitment to informal educational institutions in Kampung Inggris, Pare, Indonesia. This study hypothesizes that internal communication has a positive effect on organizational commitment. In this case, Structural Equation Modeling is used to test the second hypothesis. The results of the analysis as shown in Figure 3 show that internal communication has a significant positive effect on organizational commitment $(\beta=$ $0.441 ; \mathrm{p}<0.01)$. The results of this analysis support the second hypothesis.

The third hypothesis of this study is about the relationship between organizational commitment and employee performance in informal educational institutions in Kampung Inggris, Pare, Indonesia. This study hypothesizes that organizational commitment has a positive effect on improving employee performance. In this case, Structural Equation Modeling is used to test the third hypothesis. The analysis results as shown in Figure 3 show that organizational commitment has a significant positive effect on improving employee performance $(\beta=$ $0.483 ; \mathrm{p}<0.01)$. The results of this analysis support the third hypothesis.

The fourth hypothesis of this study is about the role of the variable organizational commitment in the relationship between internal communication and employee performance and employee performance at informal educational institutions in Kampung Inggris, Pare, Indonesia. Referring to Kenny and Baron's (1986) research, this study conducted two model analyzes, namely a model without including organizational commitment as an intermediary variable and a model that includes organizational commitment as an intermediate variable. The first model only includes variables of internal communication and employee performance. This model is intended to test the direct effect of internal communication (Figure 2). Figure 2 shows that internal communication positively and significantly affects employee performance $(\beta=0.376 ; p<0.01)$. The second model includes the three variables studied, namely internal communication, organizational commitment, and employee performance. The second model is intended to examine the indirect effect of internal communication on employee performance, namely the effect of internal communication on employee performance through organizational commitment (Figure 3). Figure 3 shows that internal communication has a positive and significant effect on employee performance $(\beta=0.182 ; p<0.05)$. In this case, the effect of internal communication on employee performance in the second model (Figure 3 ) is lower than the effect of internal communication on employee performance in the first model (Figure 2). These findings indicate that organizational commitment mediates the relationship between internal communication and employee performance. The results of this analysis support the fourth hypothesis.

\begin{tabular}{|l|l|l|}
\hline $\begin{array}{l}\text { Internal } \\
\text { communication }\end{array}$ & $\beta=0.376 ; \mathrm{p}<0.01$ & $\begin{array}{l}\text { Employee } \\
\text { performance }\end{array}$ \\
\cline { 2 - 3 } &
\end{tabular}

Figure 2

The direct effect of internal communication on employee performance 


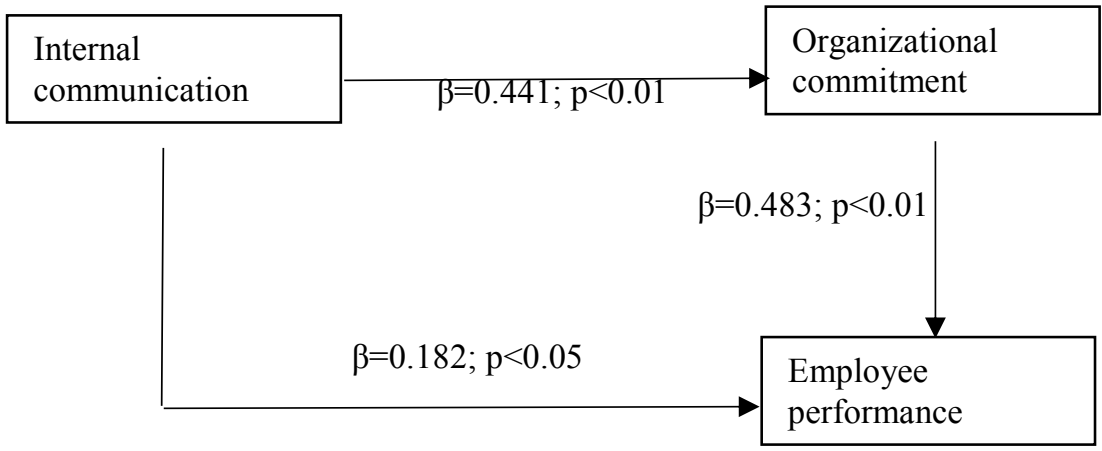

Figure 3

The indirect effect of internal communication on employee performance

\subsection{Analysis}

The findings of this study confirm that internal communication has a significant positive effect on improving employee performance in informal educational institutions in Kampung Inggris, Pare, Indonesia. These findings remind organizational leaders that communication is an important domain in the field of organization and management. Thus, as emphasized by Vercic et al. (2012), organizational leaders need to communicate with employees so that a harmonious and harmonious relationship between leaders and employees is formed. Furthermore, Vercic et al. explained that effective internal communication contributes positively to employee work performance which in turn can improve organizational performance. This is supported by the statements of experts who find a positive correlation between internal communication and employee performance (Bhatia and Balani, 2015; Kulachai et al., 2018). In addition, organizational leaders need to utilize various kinds of internal communication media to convey messages, ranging from face-to-face communication, print media, electronic media, and social networking media. However, organizational leaders need to realize that building internal communication is not a simple matter. In this case, company leaders need to build internal communication that is easy to understand, comfortable, and effective so that internal communication can contribute positively to the progress of the organization and employees feel valued by the leadership of the organization (Welch, 2013).

The findings of this study indicate that internal communication has a significant role in increasing employee commitment to informal educational institutions in Kampung Inggris, Pare, Indonesia. This finding is in line with the opinion of Bhatia and Balani (2015), who stated that if the organization consistently distributes information to all employees, the goals and values of the organization, as well as what role employees must play in their daily work, then the employee's commitment to the organization. will increase. When employees' commitment to the organization increases, employees will have a higher awareness of the goals and values of the organization. This higher awareness of the goals and values of the organization allows employees to work more efficiently towards these goals, which in turn results in greater output.

Furthermore, the findings of this study indicate that organizational commitment has a significant role in improving employee performance at informal educational institutions in Kampung Inggris, Pare, Indonesia. The findings of this study support the opinion of Hanaysha (2016), which emphasizes the importance for organizations to build organizational commitment considering that employees are the main source for obtaining sustainable performance and creating higher competitiveness. Referring to Meyer and Allen (1990), this study views that organizational commitment is a multimensional concept. This concept includes three dimensions, namely affective commitment (the employee's emotional attachment to the organization), ongoing commitment (negative impact if the employee leaves the organization), and normative commitment (the employee's desire to remain in the organization).

Kwon and Banks (2004) emphasized that employees who are committed to the organization will be willing to work effectively in the organization without any intention of switching to another organization. Highly committed employees will feel at home in the organization, have high work motivation, are active and productive, and provide support for improving organizational performance. Frone (2018) emphasizes the importance of affective commitment to organizations. This type of commitment refers to the emotional attachment between the employee and the organization and the employee's desire to be involved in every process and effort the organization makes in achieving organizational goals and objectives. Riketta (2002) suggests that organizational leaders can use affective commitment to predict employee work motivation, employee work behavior, and employee performance. This is confirmed by Gunlu et at. (2010), who explained that one of the main characteristics of organizational commitment is the involvement of individuals in the processes that take place in the organization. In addition, organizational commitment is also characterized by the willingness of employees to exert their energy and thoughts for the progress of the organization, as well as the desire of 
employees to remain in the organization.

\section{Concluding remark}

Human resources have a strategic role, especially for informal educational institutions in Indonesia. However, research on how to improve employee performance in informal educational institutions is still limited. This study aims to examine the effect of internal communication on employee performance in informal educational institutions by considering organizational commitment as a mediating variable. The findings of this study indicate that internal communication has a significant positive effect on employee performance at informal educational institutions in Kampung Inggris, Pare, Indonesia. This finding is in line with previous studies which found that internal communication and employee performance are positively correlated. However, as stated in the literature, organizational leaders need to understand the internal communication system as a whole so that they can design an internal communication system that is able to meet organizational needs (Femi, 2014; Bhatia and Balani, 2015).

This study also indicates that employee commitment to the organization has a positive effect on employee performance in informal educational institutions in Kampung Inggris Pare, Indonesia. In other words, employee commitment to the organization can encourage employee performance improvement. In addition, this study found that employee commitment to the organization was able to mediate the relationship between internal communication and employee performance. These findings support the concept put forward by some experts that employee commitment to the organization is one of the driving factors that can contribute positively to improving organizational performance. Organizational commitment allows employees to actively provide energy and ideas for the achievement of organizational goals (Gibson et al., 2008; Luthans, 2008).

\section{References}

Allen, N.J., and Meyer, J.P. (1990), "The measurement and antecedents of affective, continuance, and normative commitment to the organization", Journal of Occupational and Organizational Psychology, 63 (1), 1-18

Baron, R.M., and Kenny, D.A. (1986), "The Moderator-Mediator Variable Distinction in Social Psychological Research: Conceptual, Strategic, and Statistical Considerations", Journal of Personality and Social Psycholog, 51 (6), 1173-1182

Bhatia, K., and Balani, M. (2015), "Effective Internal Communication: a crucial factor affecting employee performance", Proceedings of International Conference on Management, Economics and Social Sciences Held in Dubai, ISBN:9788193137321

Femi, A.F. (2014), "The impact of communication on workers' performance in selected organisations in Lagos State, Nigeria", IOSR Journal of Humanities And Social Science, 19 (8), 75-82

Fletcher, M. (1999), "The effects of internal communication, leadership and team performance on successful service quality implementation”, Team Performance Management: An International Journal, 5 (5), 150163

Frone, M. R. (2018), "What happened to the employed during the Great Recession? A U.S. population study of net change in employee insecurity, health, and organizational commitment", Journal of Journal of Vocational Behavior, 107, 246-260

Giri, V.N., and Kumar, B.P. (2010), "Assessing the Impact of Organizational Communication on Job Satisfaction and Job Performance", Psychological Studies, 55 (2), 137-143

Gunlu, E., Aksarayli, M. and Percin, N.S. (2010), "Job satisfaction and organizational commitment of hotel managers in Turkey", International Journal of Contemporary Hospitality Management, 22 (5), 693-717

Hanaysha, J. (2016), "Testing the Effects of Employee Engagement, Work Environment, and Organizational Learning on Organizational Commitment", Procedia - Social and Behavioral Sciences, 229, 289 - 297

Hume, J., and Leonard, A. (2014), "Exploring the strategic potential of internal communication in international non-governmental organisations", Public Relations Review, 40 (2), 294-304

Kalla, H.K. (2005), "Integrated internal communications: a multidisciplinary perspective", Corporate Communications: An International Journal, 10 (4), $302-314$

Kulachai, W., Narkwatchara, P., Siripool, P., and Vilailert, K. (2018), "Internal communication, employee participation, job satisfaction, and employee performance", Advances in Social Science, Education and Humanities Research (ASSEHR), 186, 124-128

Kwon, I.W.G., and Banks, D.W. (2004), "Factors related to the organizational and professional commitment of internal auditors", Managerial Auditing Journal, 19 (5), 606-622

Mathieu, J.E., and Zajac, D.M. (1990), "A review and meta-analysis of the antecedents, correlates, and consequences of organizational commitment", Psychological Bulletin, 108 (2), 171-194

Men, L.R., and Stacks, D. (2014), "The effects of authentic leadership on strategic internal communication and employee-organization relationships", Journal of Public Relations Research, 26 (4), 301-324

Meng, J., and Pan, P.L. (2012), "Using a balanced set of measures to focus on long-term competency in internal 
communication", Public Relations Review, 38 (3), 484-490

Neill, M.S., and Jiang, H. (2017), "Functional silos, integration \& encroachment in internal communication", Public Relations Review, 43 (4), 850-862

Riketta, M. (2002), “Attitudinal organizational commitment and job performance: A meta-analysis”, Journal of Organizational Behavior, 23 (3), 257-266

Rukmana, H.D., Sopiah, M. and Nora, E. (2018), “The Impact of Organization Communication on Employee Performance Through Employee's Work Motivation” The First International Research Conference on Economics and Business, KnE Social Sciences, 211-227

Spanuth, T., and Wald, A. (2017), "Understanding the antecedents of organizational commitment in the context of temporary organizations: An empirical study", Scandinavian Journal of Management, 33, 129-138

Storey, D.J. (2004), "Exploring the link, among, small firms, between management training and firm performance: a comparison between the UK and other OECD countries", International Journal of Human Resource Management, 15 (1), 112-30

Vercic, A.T., Vercic, D., and Sriramesh, K. (2012), "Internal communication: Definition, parameters, and the future", Public Relations Review, 38 (2), 223-230

Welch, M. (2013), "Mastering internal communication: Knowledge foundations and postgraduate education", Public Relations Review, 39 (5), 615-617

Yeh, H (2012), "The Mediating Effect of Organizational Commitment on Leadership Type and Job Performance" The Journal of Human Resource and Adult Learning, 8 (2), 50-59

Zangaro, G.A. (2001), "Organizational commitment: a concept analysis”, Nursing Forum, 36, 14-23 